\title{
A Comparative Study: Anxiety as an Impact of Slavery in Toni Morrison's Beloved and William Faulkner's Absalom, Absalom!
}

\author{
Bhakti Satrio Nugroho \\ Universitas Gadjah Mada \\ bhakti.landt@gmail.com
}

Article History:

First Received:

$26 / 01 / 2021$

Final Revision:

$25 / 05 / 2021$

Available online:

$30 / 06 / 2021$

\begin{abstract}
This paper discusses the anxiety as an impact of slavery reflected in two outstanding African-American novels: Toni Morrison's Beloved and William Faulkner's Absalom, Absalom!. These novels are set in around the slavery period which shows how cruel and brutal slavery practices in the United States. The plots consist of some traditions and beliefs among White and African-American which have emerged since the antebellum period. By using a comparative approach, this paper focuses on the types of anxiety mentioned by Sigmund Freud. The analysis shows that both neurotic and moral anxieties play a pivotal psychological element throughout the intense "black-white" binary narratives. In this case, Toni Morrison's Beloved consists of neurotic anxiety in the form of trauma experienced by Sethe and William Faulkner's Absalom, Absalom! consist of moral anxiety in the form of shame for having Negro bloodline in aristocrat Southern plantation culture. Both novels show that slavery, whether it stands as a tradition or as an economic value, has significantly shaped the direction of American society.
\end{abstract}

Keywords: African-American, anxiety, slavery, Southern America, trauma

\section{http://ios.unsoed.ac.id/index.php/ies}

\section{INTRODUCTION}

The impact of slavery in antebellum and postbellum American society has been discussed from various perspectives including history, economics, humanities, and literary studies. Historically, enslavement has long historical references in the New World. Slavery was introduced in the middle of colonial American society by a Dutch ship that brought 20 African slaves ashore in the British colony of Jamestown, Virginia in 1619 even though the slavery culture was first introduced and developed by The Spanish and the Portuguese in the New World in 1492 (Finkelman, 2012, p. 105). In Virginia, American colonists began to use African slaves because they were cheap and plentiful labor. In this case, the 
arrival of African slaves replaced White servants who were mostly poor Europeans as workers in many plantations and households. In fact, in the $18^{\text {th }}$ century, some historians have estimated that six to seven million black slaves were imported to the New World to work mainly on the tobacco and rice plantation in Maryland, Virginia, and Georgia (Clemens, 1999, p. 1). By this far, slavery practices in the United States became a common business for slave merchants and plantation owners.

Furthermore, many scholars regard slavery in the United States as one of the cruelest practices in the world. This practice was based on the idea that slaves were wildly regarded as not human but instead a mere property by most proslavery lawyers (Allain \& Hickey, 2012, p. 916). In this case, during the colonial period, the colonial lawmakers constitutionally had to develop rules to balance the tension between treating Africans and others as persons held to labor and as property owned by other people (Finkelman, 2012, p. 106). Since the slave was considered as property, many slave owners were able to do whatever they wanted to them which included inappropriate treatments. Therefore, it increased the brutal treatments towards the slaves such as whipping shackling, beating, mutilation, branding, and sexual abuses including rape. In some states, teaching slaves to read was discouraged or prohibited due to hinder aspirations for escape or rebellion. Pregnant female slaves were still punished by lashing without harming the baby. It means that even pregnancy was not a barrier to punishment (Gray White, 2013) which shows the brutal practices of slavery in the early United States.

To increase wealth, many slaveholders aimed to influence the reproduction of slaves by breeding just like farm animals. In this case, slave breeding included coerced sexual relations between male and female slaves, promoting pregnancies of slaves, and favoring female slaves who could produce a relatively large number of children (Marable, 2000, p. 72). Therefore, slave breeding was considered a useful and profitable method to make a profit rather than purchasing new slaves.

Moreover, the intense racial clash between African-Americans, as slaves, and White people, mostly as slaveholders, has socially juxtaposed not only antebellum American society but also postbellum society as well. Therefore, guilt and ashamed were usually experienced by former slaveholders, even though it was mostly overshadowed by their pride in having a pure bloodline. At this point, for White people, the feeling of ashamed for being a mulatto or a quadroon mostly appeared due to its social prejudice within the Southern aristocrat culture as a result of the idea of "whiteness" (Wilkinson, 2013, p. vii). This idea has set the dignity of being white in Southern American society which might elevate the legal and social position (Wilkinson, 2013, p. ix). As a result, the condemnation of mixed-race had been socio-culturally accepted in early American society. Nevertheless, a "black-white" binary-based society has created racism which is then considered as America's "original sin".

Concerning this discussion, this paper tries to compare the anxiety caused by slavery in two outstanding African-American novels entitled Beloved (1987) by 
Toni Morrison and Absalom, Absalom! (1936) by William Faulkner. As AfricanAmerican literature, both novels tell their readers about the life of AfricanAmerican and mixed-race in the South. These novels promote and elaborate socioeconomic, physical, and psychological violence of White supremacy in Southern America. Morrison's Beloved is centered on Sethe's story as an ex-slave, while Faulkner's Absalom, Absalom! narrates the story of a respected White plantation owner named Thomas Sutpen. Although Absalom, Absalom! was written by the non-African-American writer, William Faulkner, it discusses the conflicting value of having mixed-race and blood purity in aristocrat Southern culture. Since the definition of African-American literature does not only rely on the writer, Absalom, Absalom!, in this case, can also be categorized as African-American literature.

Before this study, Janeen Selfridge's research entitled Beloved: The Physical Embodiment of Psychological Trauma (2018), states that the main and pivotal aspect within Beloved is the physical embodiment of Sethe's trauma which is repetitively glorified throughout the story (p. 69). Meanwhile, "Of Having Been Colored": The Racial Hybridity of Thomas Sutpen written by William Cunningham, IV (2012) shows that, in Absalom, Absalom!, the discussion of prejudice towards being "mixed-race" and the idea of "whiteness" in Southern culture has been semiotically sounded and signified, especially within the Thomas Sutpen character who lives with the proud White identity as a Southern aristocrat (p. 23). These studies signify how important both African-American literature in presenting this historical event and its implication. However, this study further involves the comparative aspect of anxiety as the impact of slavery in these novels has not been discussed.

Therefore, to enlarge the analysis towards this phenomenon, this research utilizes Sigmund Freud's types of anxiety theory: objective, neurotic and moral anxiety within the scope of comparative approach and Post-Nationalist American Studies paradigm. It also focuses on historical aspects that appear as part of this indepth discussion. This research tries to simply answer the question of how does the main characters experienced anxiety caused by slavery in both novels and its implications.

\section{Theoretical Framework}

This part explains some relevant theories used to analyze the anxiety experienced by American society which is caused by slavery reflected in two outstanding novels Toni Morrison's Beloved and William Faulkner's Absalom, Absalom!. This research is under Post-Nationalist American Studies which no longer glorifies American exceptionalism, but instead criticizing the internal issues within American society which may long have been overshadowed by the cosmetic appearance of American exceptionalism. As Rowe says, this discussion may deal with a local integrated issue in American society such as ethnicity, race, gender and women's studies, and others (2000, p. 2-3). Furthermore, the research utilizes a comparative approach to get closer to anxiety caused by slavery and highlighting some historical context that may relate to it. 
In this context, comparative literature is a study of inter-relationship between any two or more two significant literary works or pieces of literature which to analyze the meaning of two or more literary works to look for similarities and differences (Gifford, 1969, p. 45). It is a comprehensive term whose scope encompasses the totality of human experiences into its embrace, and thus all internal human relationships among the various parts of the world are realized, through the critical approach to literature under comparative study. In literary studies, it is often used to analyze literary works such as a novel, short story, drama, and poetry by comparing some aspects within the literary works including culture, setting, character, and other significant elements.

Meanwhile, Sigmund Freud describes anxiety as a feeling of impending danger that can be based on objective, neurotic, or moral threats (Hall, 1954, p. 60). Furthermore, he divides anxiety into three types: objective, neurotic and moral anxiety. Those types of anxiety have their definition, including the factors which drive a human into it (Hergenhahn \& Henley, 2013, p. 506).

The first type of anxiety is objective anxiety. This kind of anxiety results from a real threat in the physical world. That is why this type of anxiety also called "real anxiety" refers to the real object. The other type of anxiety stated by Freud is neurotic anxiety. It is a result of the ego overwhelmed by the id, which threatens to express its irrationality in thoughts and behavior. There is a fear of external punishment for such expression. Hargenhahn and Harley (2013, p. 506) mentioned that the cause of this anxiety is phobia from human childhood and other traumatic events. The form of neurotic anxiety can be a phobia, trauma, and any other form of post-traumatic anxiety. Then, Moral anxiety is based on a feeling that one's internalized values are about to be compromised. There is a fear of selfpunishment for acting contrary to one's values. Moral anxiety is a function of the development of the superego. Whenever anxiety comes, the ego seeks to reduce it. Operating at the unconscious level, it employs defense mechanisms to distort or deny reality. Thus, the forms of moral anxiety can be shame and guilt (Freud in Hergenhahn \& Henley, 2013, p. 506). These forms of anxiety are used to compare and analyze the psychological aspects within these African-American novels.

\section{RESEARCH METHOD}

This research is qualitative which is a descriptive method of analyzing the text, which emphasizes the researcher's interpretation of "the meanings, concepts, definitions, characteristics, metaphors, symbols, and descriptions of things" towards the issues (Lune \& Berg, 2017, p. 12). Creswell further defines qualitative research as "a means for exploring and understanding the meaning individuals or groups ascribe to a social or human problem" $(2009$, p. 3). It focuses on the individual meaning and the importance of rendering the complexity of the discussion. Therefore, by using the qualitative method, combined with the theoretical framework, the research solidifies the researcher's interpretation of the data in which it focuses on the main character's anxieties that appear within both novels. 
Moreover, technique data analysis is needed to classify and arrange the data (Mahsun, 2005, p. 253). This research, includes (1) data selection, (2) data interpretation, and (3) data conclusion.

\section{RESULT AND DISCUSSION}

This part compares the anxiety in Toni Morrison's Beloved and William Faulkner's Absalom, Absalom!. Some aspects within these novels which show anxiety as an impact of slavery can be used as evidence to support the argumentations. The analysis of its anxiety is based on Sigmund Freud's types of anxiety mentioned in An Introduction to the History of Psychology (2013) by Hergenhahn and Tracy Henley, To ease the comprehension, this discussion in this paper is divided into three: neurotic anxiety in Toni Morrison's Beloved, moral anxiety in William Faulkner's Absalom, Absalom! and the comparison of the anxiety.

\section{a. Neurotic Anxiety in Toni Morrison's Beloved}

In Toni Morrison's Beloved, the post-traumatic signs of neurotic anxiety seem to be the important aspect throughout the story. The way White people treated her during slavery has psychologically haunted her. As an ex-slave, the main character, Sethe, is suffered from the horrible treatment of slavery in Mr. Garner's plantation, Sweet Home along with her husband, Halle, Paul D, Paul A, Paul F, Sixo, and earlier her mother-in-law, Baby Suggs. After the death of Mr. Garner, the School teacher is in charge of Sweet Home. In this case, he is cold, sadistic, and vehemently racist because he is against Garner's too-soft approach with an oppressive regime of rigid rules and punishment on the plantation.

Toni Morrison's Beloved illustrates physical violence towards AfricanAmericans which later psychologically manifested into post-traumatic forms. In the first chapter, the arrival of Paul D in 124 on Bluestone Road, Sethe's house, reveals that Sethe was pregnant during her escape. She also describes she was whipped on her back until she has permanent whipping scars on her back which she metaphorically calls as "chokeberry tree",

“Whitegirl [Amy Denver]. That's what she called it [Sethe's whipping scar]. I've never seen it and never will. But that's what she said it looked like. A chokecherry tree. Trunk, branches, and even leaves. Tiny little chokecherry leaves. But that was eighteen years ago. Could have cherries too now for all I know" (Morrison, 2004, p. 16).

In this case, Sethe's "chokeberry tree" is a permanent scar as a result of physical tortures by the new Sweet Home plantation owner, a Schoolteacher who is known as a racist White person. In the slavery period, slaves usually had to whip scars on their back because whipping was considered a common punishment to the slaves, whether they were male or female (Gray White, 2013). For the slaveholders, conducting physical punishments is a way to justify and strengthen their racial 
status. It is an act of maintaining their superior dignity based on the idea of "whiteness" which victimizes their slaves.

In this novel, the physical tortures towards slaves by Schoolteacher were very intense and constant and almost occurred on daily basis, "It's sitting there. Sleeps, eats and raises hell. Whipping Sethe every day" (Morrison, 2004, p. 255). As Freud says, this constant act of violence predominantly results in psychological breakdown later in someone's life, which can be seen in Sethe's post-slavery life in 124.

Moreover, the practice of slave dehumanization is applied in most of the Southern plantations to justify and implement the idea of "whiteness" towards their slaves. In this case, unlike Mr. Garner, Schoolteacher often compares White people and their slaves by asking questions and taking physical measurements. It then becomes teaching lessons to his pupils that Sethe has "animal characteristics", "I [Schoolteacher] told you to put her [Sethe's] human characteristics on the left; her animal ones on the right" (Morrison, 2004, p. 193). Therefore, since Schoolteacher and many White slave owners at that period considered slaves as an animal, they could treat and punish them as animal as well such as whipping, beating and even branding. It is the idea of coercive establishment of White superiority that marginalizes the slaves as a commodity in which they are treated as property, not as a human. Therefore, just like an animal farm, the notion of slave-breeding, for these slaveholders, was considered as a morally acceptable act.

Furthermore, the form of dehumanization also consists of sexual abuse. In this novel, Sethe was sexually abused by Schoolteacher and his fellows by drinking her breast milk,

"They [Schoolteacher and his fellows] used cowhide on you?" [Paul D]

"And they took my milk." [Sethe]

"They beat you and you were pregnant?"

"And they took my milk!"

- (Morrison, 2004, p. 17)

This dialogue shows that sexual abuse practices also happened in Sweet Home plantation. As a female slave, Sethe was not considered as human but rather as an animal by Schoolteacher and his fellows. It is a Schoolteacher's justification to do that sexual abuse act to his female slaves. For these White people, this sexual abuse act is like drinking milk straight from a milk cow without considering that Sethe is a human being.

As the consequents of the physical and mental tortures as a female slave, during her life in 124 with her daughter, Denver, Sethe begins to recall her neurotic trauma after the arrival of Paul D, who was also a former slave in Sweet Home plantation along with her husband, Halle. She begins to recall her horrible past as a slave and her experience escaped from the Sweet Home plantation. Sethe explains that she killed her second daughter by cutting her throat and injured her other children when Schoolteacher and other three horsemen, a nephew, a slave catcher, and a sheriff came to her house, 124 on Bluestone Road to claim his right 
upon his fugitive slaves. It shows that the arrival of these four White horsemen triggers Sethe's neurotic trauma which then manifested by killing one of her daughters and injuring others. Because of this tragic occasion, Sethe was freed by Schoolteacher because she was considered too insane to be a slave again. In a later chapter, she justifies her tragic murder act by saying,

“I'll [Sethe] explain to her, even though I don't have to. Why I did it. How if I hadn't killed her she [Beloved] would have died and that is something I could not bear to happen to her" (Morrison, 2004, p. 200).

In this case, she killed her daughter (later named Beloved) because she does not want her daughter and other children to experience the same thing that happened to her as a slave. In other words, it shows that even after live far away from the Sweet Home plantation, Sethe is still haunted by her horrible past as a slave. She does not want that experience to come again and also does not want that to happen to her children. In this case, dehumanized acts towards Sweet Home plantation slaves can be the main factor of Sethe's trauma and neurotic anxiety throughout the story even though she no longer lived and became part of Sweet Home plantation.

Moreover, her surrounding people such as Denver and Paul D are aware that Sethe has suffered from her traumatic experiences as a slave in Sweet Home plantation. Denver, who later supports Sethe and Beloved after Sethe quitted from her job, says,

"All the time, I'm [Denver] afraid the thing that happened that made it all right for my mother [Sethe] to kill my sister [Beloved] could happen again. I don't know what it is, I don't know who it is, but maybe there is something else terrible enough to make her do it again" (Morrison, 2004, p. 206).

It shows when Beloved shows up in 124 on Bluestone Road and began live with Sethe and Denver, Sethe is triggered by her long tragic trauma which drives her to insanity. At the end of the story, she begins to realize that Beloved is a ghost of the daughter whom she killed. She begins to show her full affection as a mother to Beloved and fulfills almost anything that Beloved's wanted. Meanwhile, Denver realizes her mother's insanity and began to seek a job to replace her mother as the breadwinner of the family.

By this explanation about Sethe's traumatic experiences and insanity, it shows that Sethe, as a former slave, undergoes trauma as a form of neurotic anxiety. This trauma has resulted from the dehumanized practices of slavery such as daily physical torture and sexual abuse in Sweet Home plantation after the Schoolteacher replaces Mr. Garner's family. The painful and inhumane treatments are the main factors that traumatize Sethe even after she gets her freedom and no longer becomes a slave. According to Sigmund Freud (in Hergenhahn \& Henley, 2013 , p. 506), trauma is part of neurotic anxiety which can haunt the person who is suffered from it. It is a type of anxiety that deals with neurotic (brain) which can be a long-term form of anxiety. Cathy Caruth, in her seminal study Unclaimed 
Experience (1995), has defined trauma as an event that is not experienced but simply registered, as it overwhelms the person to whom it happens.

Thus, by looking at all of the cruel and brutal practices of slavery in Sweet Home plantation, it shows that Sethe, as a former slave, experiences trauma which then triggered by the arrival of her past to 124 on Bluestone Road (Schoolteacher, Paul D and Beloved). This trauma is then manifested by the act of killing her daughter (to avoid them from getting captured by the Schoolteacher, her former owner) and other acts to fulfill Beloved's needs. Those are clear evidence that trauma as a form of neurotic anxiety appears in Toni Morrison's Beloved which is a result of slavery.

\section{b. Moral Anxiety in William Faulkner's Absalom, Absalom!}

Meanwhile, in William Faulkner's Absalom, Absalom!, the form of anxiety can also be found as a consequence of slavery. Unlike in Toni Morrison's Beloved, the anxiety that appears is instead experienced by White and other mixed-race people. In this case, William Faulkner's Absalom, Absalom! sets before, during, and after Civil War in the South. In other words, it means that this novel sets during and after the slavery practice which still underwent high racial tension and prejudice towards Black people. This story narrates the life of a Southern aristocrat named Thomas Sutpen and his family Henry, Judith, Charles, Rosa, Clytie, and other minor characters. They lived on a plantation called Sutpen Hundred in Yoknapatawpha County, Mississippi. The main conflict in this story is when Charles Bon who is then revealed as Thomas Sutpen's son from his former marriage comes to Sutpen Hundred and wants to marry Judith, his half-sister.

However, before Thomas Sutpen moved to build his plantation and mansion in Yoknapatawpha County, Mississippi, it reveals that Thomas Sutpen has a shameful history for Southern tradition which he wanted to forget. According to Mr. Compson's story to his son, Quentin, it shows that Thomas Sutpen learns that his first wife has Negro blood and repudiates her and child, later in the story known as Charles Bon,

"Grandfather [General Compson] said the only mention he [Thomas Sutpen] ever made to those six or seven years which must have existed somewhere, must have actually occurred, was about the patois he had to learn in order to oversee the plantation, and the French he had to learn, maybe not to get engaged to be married, but which he would certainly need to be able to repudiate the wife [Charles Bon's mother] after he had already got her-how, so he told Grandfather, he had believed that courage and shrewdness would be enough but found that he was wrong and how sorry he was that he had not taken the schooling along with the West Indian lore when he discovered that all people did not speak the same tongue and realized that he would not only need courage and skill, he would have to learn to speak a new language, else that design to which he had dedicated himself would die still-born". (Faulkner, 1972) 
In this case, Thomas Sutpen tries maintaining the purity of his bloodline by repudiating his ex-wife and child because mixed-race born was considered a shameful disgrace, especially in the South. It is against the value of "whiteness" that he believes in as a white Southerner.

Historically, in the history of the United States, this White supremacist tradition and the idea of "whiteness" were rooted within American society since the American colonial period. Howard Zinn in his book entitled A People's History of the United States, 1492-Present, explains that sexual intercourse and interracial marriage between White and Black were prohibited by law in Southern states including Virginia, Massachusetts, Maryland, Delaware, Pennsylvania, the Carolinas, and Georgia. This prohibition was used to keep Negro inside the Black families so that the White population could remain "pure" and in control (Zinn, 1999, p. 51). Despite the prohibition law, mixed offspring continued to be produced by White-Black fraternization throughout the colonial period which made them become "in-between people" who could not be socially accepted in both races. Thus, for White people, having a Negro bloodline or mixed-race offspring such as mulatto, quadroon and octoroon were considered a disgrace since the Southern society still believed in the White purity tradition.

In this story, after finding that his wife has Negro bloodline, Thomas Sutpen decides to leave and repudiate his former family including Charles Bon. With the feeling of shame, he later moves to Yoknapatawpha County, Mississippi to build his new plantation by buying land from Indian Tribe. With the help of his French architect, he manages to build Sutpen Hundred and his huge mansion. To gain much reputation, he decides to marry Ellen Coldfield who is a daughter of a reputable merchant and Methodist named Mr. Coldfield, to maintain his social status as a White slaveholder and plantation owner,

"But Sutpen wanted it. He wanted, not the anonymous wife and the anonymous children, but the two names, the stainless wife and the unimpeachable father-in-law, on the license, the patent." (Faulkner, 1972)

In this case, he does not want to repeat his past by marrying an anonymous woman who potentially had a mixed-race bloodline like his former wife. This act evokes the condemnation of having "mix-blood" within the Southern society where Thomas Sutpen lives. As a reputable plantation owner and slaveholder, he does not tolerate having "Negro-bloodline" in his family. This anxiety later haunts him when his pasts come back to his present life in Mississippi. Thus, this explanation, shows that Thomas Sutpen experiences anxiety of having a mixed-race bloodline in the form of shame.

According to Lewis (1987, p. 41), shame is a sense of smallness, worthlessness, and powerlessness in a given situation, which also part of the emotional and psychological makeup of every human being. This feeling is a form of moral anxiety that happens to Thomas Sutpen. In this case, Thomas Sutpen experiences shame for having a mixed-race bloodline from a previous marriage. 
This feeling then haunts him throughout the story, especially when Charles Bon comes to his new family in Christmas with Henry Sutpen.

Furthermore, his shame is further manifested by prohibiting Charles Bon's desire to marry his daughter, Judith. Although the prohibition is based on the fact that Charles Bon is supposedly also Thomas Sutpen's son from a previous marriage, he first tells his son, Henry, that Charles Bon has Negro bloodline,

"He [Charles] must not marry her [Judith], Henry. His mother's father told me that her mother had been a Spanish woman. I [Thomas] believed him; it was not until after he was born that I found out that his mother was part Negro". (Faulkner, 1972)

By knowing that Charles Bon has Negro bloodline, it triggers his anxiety in the form of shame of having a mixed-race bloodline. It also emphasizes that in the South during that time, having mixed-race blood was considered a disgrace and something that could not be socially accepted. Clytie, who is Thomas Sutpen's mixed-race daughter from a slave woman, cannot be solely accepted by Ellen's sister, Rosa Coldfield. In Rosa's narration in this story, she hesitates and even refuses to share a bed with Clytie and does not accept her as part of the Sutpen family.

By looking at all of this evidence happen to Thomas Sutpen and his family, it shows that for White people at that time, slavery also further creates discrimination among the society not only between White and Black but also within White society themselves. Many conflicts in this story such as Henry and Charles conflict, Rosa and Clytie conflict, and Thomas Sutpen and his former family conflict appear as a result of intense racial discrimination in the slavery period. In this case, slavery which looked at Black people as animals and property cause various conflicts within White society such as prejudice, guilt, and shame. Furthermore, shame drives Thomas Sutpen to repudiate his former family and to reject Charles Bon's proposal to marry his daughter, Judith, which later triggers a tragic conflict between Henry and Charles. In other words, Thomas Sutpen's shame is the main factor that destroys his own family and legacy. Thus, as being said above that shame is part of moral anxiety explained by Sigmund Freud (in Hergenhahn \& Henley, 2013, p. 506) which means that by looking at all those pieces of evidence dealing with his shame, it is a clear explanation that Thomas Sutpen experiences moral anxiety in the form of shame. It shows that in William Faulkner's Absalom, Absalom! also consists of moral anxiety experienced by White people.

\section{c. Comparison of the Anxiety in Both Novels}

Both Toni Morrison's Beloved and William Faulkner's Absalom, Absalom! consist of a psychological impact and consequence of slavery and intense racial clash and discrimination. By comparing both novels, the anxiety that the main characters experience functions as a tragic flaw within the narratives which subsequently causes the characters' downfall at the end of the story. 
In Toni Morrison's Beloved, the main character, Sethe experiences neurotic anxiety in the form of trauma. It is caused by the cruel treatment of the Schoolteacher in the Sweet Home plantation after he replaces the Garner family. Dehumanization towards the slaves such as whipping and sexual abuses traumatizes Sethe even after she lives as a free woman in 124 on Bluestone Road. The arrival of the Schoolteacher, his nephew, a sheriff, and slave catcher, triggers her trauma which manifested by killing her infant daughter and injuring her other children. When Paul D and Beloved come to her house, it re-imposes the horrible past into Sethe's life. She begins to memorize and recall her memories as a slave. After she realizes that Beloved is the ghost of her dead daughter, she begins to shower her with many affections that she has and fulfill Beloved's wants. Thus, neurotic anxiety seems to be the main plot in Toni Morrison's Beloved.

On the other hand, in William Faulkner's Absalom, Absalom! the anxiety is not experienced by African-American characters but rather experienced by White characters, specifically Thomas Sutpen. The form of anxiety is not neurotic but rather moral anxiety in the form of shame experienced by Thomas Sutpen. His anxiety is centered on his stance to maintain the White purity of his bloodline. He repudiates her former marriage and rejects Charles Bon's proposal for marrying his daughter because of Charles' octoroon bloodline. In other words, Thomas Sutpen's shame is a tragic flaw that then destroys his family legacy. Nevertheless, as a form of moral anxiety, shame seems to be the main plot in William Faulkner's Absalom, Absalom!.

Furthermore, both Toni Morrison's Beloved and William Faulkner's Absalom, Absalom!. psychologically demonstrate the reappearance of the horrible pasts of the main characters, Sethe and Thomas Sutpen which then leads them into conflicts throughout the story. For Sethe, the reappearance of the Schoolteacher and his associates, and Paul D, has psychologically deluded her sanity. The horrible images of slavery reappear even though she is now a free African-American woman. Meanwhile, for Thomas Sutpen, the reappearance of Charles Bon as an embodiment of his past creates substantial damage to his family and later to his mental wellness as well.

\section{CONCLUSION}

In conclusion, Morrison's Beloved and William Faulkner's Absalom, Absalom! consist of two different types of anxiety caused by the cruelty of slavery treatments and the intense racial discrimination during the slavery period. Furthermore, based on the comparative analysis, both novels emphasize two different types of anxiety experienced by the main characters, Sethe in Toni Morrison's Beloved and Thomas Sutpen, in William Faulkner's Absalom, Absalom!. In Toni Morrison's Beloved, Sethe's post-slavery life represents the climax of her traumatic experience from what she received during her enslavement in Mr. Garner's plantation. It represents the unerasable scar in the form of mental and psychological damages that an ex-slave would possibly perceive even after the slavery period. Meanwhile, in William Faulkner's Absalom, Absalom!, the intense racial hate during the slavery period has psychologically affected a racist White character like Thomas Sutpen 
who used to be proud of "his pure blood". Thus, both novels show that slavery has significantly impacted many social, racial, and cultural aspects of the modern American society in which racism seems to be strongly embedded and cannot be easily erased. In further discussion, these narrations implicitly tackle the idea of "whiteness'" as a source of social balance that had been long preserved as part of Southern American culture.

\section{REFERENCES}

Allain, J. \& Hickey, R. (2012). Property and The Definition Of Slavery. International and Comparative Law Quarterly, 61, 915-938 doi:10.1017/S0020589312000450

Caruth, C. (1995). Unclaimed Experience: Trauma, Narrative, and History. Baltimore: Johns Hopkins UP.

Clemens, P. (1999). Before Cotton and Other than Sugar: How Tobacco and Rice Shaped the World of Eighteenth-Century Slaves in British North America. Reviews in American History Vol. 27. 1-7

Creswell, J. (2009). Research Design: Qualitative, Quantitative, and Mixed Methods Approaches. Los Angeles: SAGE Publication.

Cunningham IV, W. (2012). "Of Having Been Colored": The Racial Hybridity of Thomas. A Master's Degree Thesis. Alabama: The University of Alabama

Faulkner, W. (1972). Absalom, Absalom!. New York: Vintage Books.

Finkelman, P. (2012). The Legal Understanding of Slavery: From the Historical to the Contemporary. The United States: Oxford Scholarship.

Gifford, H. (1969). Comparative Literature. New York: Humanities Press.

Gray White, D. (2013). Freedom on My Mind: A History of African Americans. Bedford/ St. Martins.

Hall, C. S. (1954). A Primer of Freudian Psychology. Cleveland: World.

Hergenhahn, R. \& Henley, T. (2013). An Introduction to the History of Psychology: Seventh Edition. Wadsworth: Cengage Learning.

Lewis, H. (1987), The Role of Shame in Symptom Formation. New York: Springer Science+Businnes Media.

Lune, H., \& Berg, B. (2017). Qualitative Research Methods for the Social Sciences. Malaysia: Pearson Education Limited.

Mahsun. M. (2005). Metode Penelitian Bahasa: Tahapan Strategi, Metode, dan Tekniknya. Jakarta: PT. Raja Grafindo Persada.

Marable, M. (2000). How Capitalism Underdeveloped Black America: Problems in Race, Political Economy, and Society New York: South End Press.

Morrison, T. (2004). Beloved. New York: Vintage International.

Rowe, J. (2000). Post-Nationalist American Studies. Berkeley: University of California Press.

Selfridge, J. (2018). Beloved: The Physical Embodiment of Psychological Trauma. Midwest Journal of Undergraduate Research 2018, Issue 9, 68-83

Wilkinson, B. (2013). Blurring the Lines of Race and Freedom: Mulattoes in English Colonial North America and the Early United States Republic. A Ph.D. Dissertation. Berkeley: The University of California.

Zinn, H. (1999). A People's History of the United States, 1492-Present. New York: Harper Perennial Modern Classics. 